\title{
A reply to the comment on "Assessing preservation priorities of caves and karst areas using the frequency of endemic cave-dwelling species" by Nitzu et al. (2018), Int. J. Speleol., 47 (1): 43-52
}

\author{
Eugen Nitzu, Ioana N. Meleg*, and Andrei Giurginca \\ "Emil Racoviță" Institute of Speleology, Romanian Academy, Calea 13 Septembrie, 050711, Bucharest, Romania
}

Keywords: $\quad$ cave fauna, karst, preservation, Romania

Received 30 December 2018; Revised 12 February 2019; Accepted 13 February 2019

\begin{abstract}
Citation: Nitzu E., Meleg I.N. and Giurginca A., 2019. A reply to the comment on "Assessing preservation priorities of caves and karst areas using the frequency of endemic cave-dwelling species" by Nitzu et al. (2018), Int. J. Speleol., 47 (1): 43-52. International Journal of Speleology, 48 (1), 111-113. Tampa, FL (USA) ISSN 0392-6672 https://doi.org/10.5038/1827-806X.48.1.2245
\end{abstract}

We appreciate the attention of our two colleagues, Oana Teodora Moldovan (OTM) and Traian Brad (TB), to our article "Assessing preservation priorities of caves and karst areas using the frequency of endemic cave-dwelling species" (hereafter referred to as IJS2018). Due to space limitation, we will address in short their comment (hereafter IJS-Comment) on IJS2018 Article.

The IJS-Comment reflects a misunderstanding and erroneous interpretation of the data and basic aim of IJS-2018: to propose a tool based on the principle of using endemic species to assess the patrimonial value of caves and consequently their conservation and management needs in terms of their biological peculiarities. IJS-2018 didn't propose: 1) to discuss the correctness of systematics, once species are listed in recognized international systematic databases; 2) to address issues related to "external threats"; and 3) to ignore the current regulations, but to provide scientific support needed for regulatory framework implementation and improvement. Moreover, the IJS-2018 authors: 1) didn't claim that inventories or databases are complete; and 2) based their proposed index on several groups of Arthropoda. It is self-explanatory that instruments for data collection and management are perfectible and constantly updated. Therefore the proposed index and its concept may be extended beyond Arthropoda based on identified in situ needs.

To start with, some of the comments in IJS-Comment refer to another paper of ours (Nitzu et al., 2016), and not to IJS-2018. Since Nitzu et al. (2016) dataset was used in IJS-2018, we will reply to all comments on both papers.

In the introductory part of their comment, OTM and TB raised the problem of type of errors in IJS-2018 that "encumber the correct and equitable protection of cave species". Starting with the introductory part of IJS-Comment, OTM and TB misstated: "The authors' viewpoint is that the occurrence of cave dwelling species ... in 3-4 caves up to a maximum 37 caves can be used to rank the caves..." In reality, we mentioned (p. 44) that we have taken into consideration all endemic arthropod species known up to present to inhabit the caves from the studied area, starting from one cave (unique species) to the maximum counted number of caves (see Table 1 and all discussion from 46 caves in our paper).

We turn now to a discussion of the so-called "type errors" in IJS-Comment.

\section{1) Answer to the "type 1 error".}

The affirmation of OTM and TB is incorrect. In our paper, in the supplemental "Annex 1", Peştera Vântului (Cave) is ranked on the 46-th position of the total of 380 (E.I. = 1.62), taking an important place in the classes of conservation concern, as we have mentioned in our article (p. 48, paragraph 1).

Regarding the number of endemic cave-dwelling species from Vântului Cave, we referred to the Arthropod fauna, the best studied for over 100 years in the area (see introductory part in Nitzu et al., 2016). And yes, from the total number of endemic cave dwelling Arthropoda recorded in the Vântului Cave, only six fulfilled the selection criteria.

We agree that "repeated sampling is needed in order to be certain that a species is present in one or more caves", but we have worked with all reliable data available up to present of biospeleological studies on Arthropoda (see Nitzu et al., 2016). 
OTM and TB observed that "out of more than 12,000 caves known in Romania, 830 are considered in Nitzu et al. (2016), with many others that might be biospeleologically overlooked". There is a relatively high possibility that some endemic-cave dwelling arthropods exist in new other caves, others could be described in the future, but we worked with all known data available on this subject, as such the number of assessed caves (in the studied area) with endemic cave-dwelling arthropods (see p. 44, "Dataset" from Nitzu et al., 2016).

As for the remark of OTM and TB on the rich cave fauna of Lazului Cave, the authors seem to forgot that we refer only to the endemic cave dwellers, not to all the species inventoried in this cave. If OTM and TB know other species of endemic cave-dwelling Arthropoda species, other than those mentioned by us in the catalogue (Nitzu et al., 2016), we ask them to ground their affirmation.

\section{2) Answer to "type II error".}

OTM and TB claimed that "We argue that endemic species should be only considered when isolated populations are present in specific areas characterized by particular geological features".

We were unable to see where they "argued" such a theory. Instead, in our article IJS-2018, at methodology (p. 44) we defined the term endemic reported to the specific geographic area, and based on the bibliography used for the accepted definition of endemism.

We do not understand what are the arguments of OTM and TB regarding the presence of endemisms in a heterogeneous landscape, but as it could be observed in IJS- 2018, 131 taxa were found only in one cave, and only five species have been found in 23 to 37 caves (Table 1, p. 46), most of them in the same mountain massif (Nitzu et al., 2016) and Fig. 2 IJS-2018.

Taxa related misstatements: the authors are making assumptions without presenting any proof for their affirmations.

1. The affirmation that Trachelipus trilobatus was found in Poland and Orthonychiurus ancae is present in Slovenia.

All the papers concerning the genus Trachelipus agree on the status of Romanian endemite for Trachelipus trilobatus: Schmidt (1997), Schmalfuss (2003), Tabacaru \& Giurginca (2013), and Tomescu et al. (2015). So, it would be better if the authors of the IJS-Comment will cite here the paper on this matter, otherwise the affirmation is null. On the other hand, if their affirmation is based on the maps from Fauna Europaea, then it has no value since Fauna Europaea contains numerous errors concerning the Oniscidea and as such is not reliable. To mention just one glaring error: their inclusion of five species of Mesoniscus (see Jong et al., 2014) when there are only two, a fact argued exhaustively in 1963 by Gruner and Tabacaru and included by Schmalfuss in 2003 in his world catalogue of Oniscidea. The same observation for Orthonychiurus ancae (see Gruia, 2003).
2. The affirmation "There are also troglophilic species with wide distribution in Romania. For example, Hyloniscus flammuloides ...", this does not come from Tabacaru \& Giurginca (2013). The paper does not claim that Hyloniscus flammuloides might have a possible more extensive distribution. There is nothing in the mentioned paper even slightly suggesting or supporting this affirmation. And in any case, Hyloniscus flammuloides is not "an example of a troglophilic species with wide distribution in Romania". The species Hyloniscus flammuloides is recorded in only two locations (see Giurginca et al., 2015, pages 38 and 121). Is this "a possible more extensive distribution" or just an affirmation without support?

3. Amphipoda

The name of the species presented in IJS-2018 and Nitzu et al. (2016) are listed in Fauna Europaea, https://fauna-eu.org/cdm_dataportal. All the other comments related to amphipods have no reference in the IJS-2018, nor Nitzu et al. (2016): we never reported Niphargus ablaskiri variabilis, Niphargus bihorensis as species recorded in a single cave (see the detailed list in Nitzu et al., 2016). As for the presence of Niphargus stygocharis stygocaris, our aim was to list its presence in cave habitats, since Nitzu et al. (2016) and IJS-2018 deal with cave habitats. However, the presence of $N$. $s$. stygocharis in other groundwater habitats within the same hydrographic basin is no doubt obvious, as for other groundwater species. Consequently, that is one of the reasons, among others, for proposing a $10 \mathrm{~km}^{2}$ area for mapping the karst area vulnerability.

\section{3) Answer to "type III error".}

OTM and TB seem to forgot that we referred to the endemic troglophilic species (eutroglophilic species are dependent in a certain phase of their onthogenesis by the subterranean habitat), and yes, these endemic troglophilic species are also important in the protection of karst areas. For more discussions on this subject please see p. 48 in IJS-2018. If OTM and TB argue that "trogophilic species might be mentioned in dozen of caves", while further suggesting that "is no study on their presence", then, based on what they sustain their affirmation?

\section{4) Answer to "type IV error"}

In IJS-2018 we have not "ranked species" as OTM and TB affirmed, but caves, and this was made on the accumulated reliable data up to present. The periodically sampling and adjustment could be possible in time. In the chapter "Conclusions" (p. 50) we have mentioned that "the proposed EI was generated as a solution for prioritization of small and isolated habitats at medium scale, different by the suitable solutions available... for large scale areas". Moreover, Rabelo et al. (2018) have tested our EI in a large karst area of Brazil, and their conclusion was that "The EI (Nitzu et al., 2018) has shown to be a great index for the conservation of endemic cave dwellers but requires an accurate database of the distribution of the troglobiotic species to be satisfactorily applied". 
5) Answer to "Type V error".

There is no published "red list of Arthropoda" for Romania, so we do not see the sense of this comment here.

Regarding a unique representative of the genus "Romanosoma" (correct Hylebainosoma)", indeed, Tajovsky et al. (2014) argued that the genus Romanosoma is not valid and included Romanosoma in Hylebainosoma. In IJS-2018 we have followed here the opinion of Mauriès (2015), which not only validates Romanosoma but also regards it as distinct from Hylebainosoma. That Romanosoma is a valid genus is also the opinion of Kime \& Enghoff (see de Jong et al., 2014).

"In the same region, Peştera de la Izvorul Tăuşoarelor, absent in the list of Nitzu et al. (2016), is the habitat of Litocampa humilis comani" (Sendra et al., 2012)." Yes, that was an omission in Nitzu et al. (2016).

\section{6) Answer to "type VI error".}

Assessing the potential threats was not the purpose of the IJS-2018, but to prioritize the caves for protection from bispelolological point of view (see more at p. 50). Another erroneous affirmation of OTM and TB is that we stipulated in our article that only caves from the red zone (those with highest EI) should be protected and the others not. On the contrary, at p. 48, we emphasized that the caves with EI from 1.94 to 1 , despite their lower diversity in terms of endemic taxa compared to those from the first cluster, should be regarded and protected. Please see also our comment from point (1).

\section{7) Answer to "type VII error".}

Here we address only specific points related to cave protection regulation in Romania and not the personal interpretations that most of the time, have no reference in IJS-2018. To start with, article 8 of the Emergency Government Ordinance 57/2007 (Ordonanța de Urgență a Guvernului 57/2007, hereafter OUG 57/2007), the law for natural protected areas in Romania, establishes the designation and the regime of the natural protected areas (IUCN categories, Natura 2000). Moreover, for caves designated as natural protected areas, the article 43 of the OUG $57 / 2007$ classifies the caves in four classes of protection based on their patrimonial value assessed through specific scientific studies. According to the law 5/2000 and Government Decision (Hotărârea) $2151 / 2004$, out of 12,000 caves, only 132 caves are designated natural protected areas (i.e., nature reserve/monument) and are classified based on their patrimonial value. In this context, the EI proposed in IJS-2018 is a valuable tool that may be used for assessing the biological patrimonial value of caves, in support of cave designation as natural protected areas and their classification.

\section{ACKNOWLEDGMENTS}

This work was financially supported by the "Emil Racoviță" Institute of Speleology (Romanian Academy) within the Project 1 of the Program I framework.

\section{REFERENCES}

Giurginca A., Munteanu C.M., Vlaicu M. \& Tabacaru I.G., 2015 - Cavernicolous Oniscidea of Romania. "Semne" Publishing House, Bucharest, Romania, 166 p., ISBN: 606-15-0673-2.

Gruia M., 2003 - Collembola from Romanian caves. Travaux du Museum d'Histoire Naturelle „Grigore Antipa", 35: 139-158.

Gruner H.E. \& Tabacaru I., 1963 - Revision der Familie Mesoniscidae Verhoeff, 1908 (Isopoda, Oniscoidea). Crustaceana, 6: 15-34. https://doi.org/10.1163/156854063X00318

Hotărârea nr. 2151/2004 privind instituirea regimului de arie naturală protejată pentru noi zone.

Jong de Y., Verbeek M., Michelsen V., Bjørn P.P , Los W., Steeman F., Bailly N., Basire C., Chylarecki P., Stloukal E., HagedornG., Tobias Wetzel F., Glöckler F., Kroupa A., Korb G., Hoffmann A., Häuser C., Kohlbecker A., Müller A., Güntsch A., Stoev P. \& Penev L, 2014 Fauna Europaea - all European animal species on the web. Biodiversity Data Journal, 2: e4034. https://doi.org/10.3897/BDJ.2.e4034

Legea nr. 5/2000 privind aprobarea Planului de amenajare a teritoriului național - Secțiunea a III-a zone protejate.

Mauriès J.P., 2015 - Platydesmidan and polyzoniidan millipedes collected in the Northwest of Iberian Peninsula by British expeditions in 1993 and 2004 (Diplopoda: Platydesmida, Polyzoniida). Russian Entomological Journal, 24 (4): 325-341.

Nitzu E., Giurginca A., Nae A., Popa I., Baba S., Meleg I.N. \& Vlaicu M., 2016 - The catalogue of caves with endemic cavernicolous arthropod fauna of Romania. Travaux de 1'Institut de Spéologie "Emile Racovitza", 55: 3-62. http://www.speotravaux.iser.ro/16/art01.pdf

Ordonața de Urgență a Guvernului nr. 57 / 2007 privind regimul ariilor naturale protejate, conservarea habitatelor naturale, a florei şi faunei sălbatice, aprobată cu modificări şi completari prin Legea nr. 49/2011, cu modificările şi completarile ulterioare.

Rabelo L.M., Souzo-Silva M. \& Ferreira R.L., 2018 Priority caves for biodiversity conservation in a key karst area of Brazil: comparing the applicability of cave conservation indices. Biodiversity Conservation, 27 (9): 2097-2129. https://doi.org/10.1007/s10531-018-1554-6

Schmidt C., 1997 - Revision of the European species of the genus Trachelipus Budde-Lund, 1908 (Crustacea: Isopoda: Oniscidea). Zoological Journal of Linnean Society, 121: 129-244.

https://doi.org/10.1111/j.1096-3642.1997.tb00337.x

Schmalfuss H., 2003 - World catalog of terrestrial isopods (Isopoda: Oniscidea). Stuttgarter Beitrage zur Naturkunde, Serie A 654: 341 p.

Tabacaru I. \& Giurginca A., 2013 - Cavernicolous Oniscidea of Romania. Travaux de 1'Instut de Spéologie "Émile Racovitza", 52: 3-26. http://www.speotravaux.iser.ro/13/art01.pdf

Tajovský K., Mock A. \& Papáč, V.,2014 - The genus Hylebainosoma Verhoeff, 1899 (Diplopoda, Chordeumatida, Haaseidae): Redescription of Hylebainosoma tatranum, description of a new troglobiont species and notes to the Hylebainosoma-Romanosoma species group. Zootaxa, 3764 (5): 501-523. https://doi.org/10.11646/zootaxa.3764.5.1

Tomescu N., Teodor L.A., Ferenți S. \& Covaciu-Marcov S.D., 2015 - Trachelipus species (Crustacea, Isopoda, Oniscidea) in Romanian fauna: morphology, ecology, and geographic distribution. North-Western Journal of Zoology, 11 (Supplement 1): S1-S106. http://biozoojournals.ro/nwjz/content/v11s1/nwjz e150301 Tomescu.pdf 